Historic, Archive Document

Do not assume content reflects current scientific knowledge, policies, or practices. 



\section{Price's Black Beauty Dewberry}

A Sport from Austin, most wonderful berry, large to very large long berries, one inch in diameter and one to one and one-quarter inch in length. The mother plant has been bearing these large uniform berries for 13 years and all plants I have are propigated from the mother plant, a very strong brier and heavy bearer. Only a few plants to offer this season at $\$ 4.00$ per 100 .

\section{J. E. PRICE, Prop:}

PILOT POINT DEWBERRY FARM

Pilot Point, Texas 




